\title{
A Descriptive Study on the Use of Colloquial Style in English Songs
}

\author{
Endriana Sri Wahyuni \\ SD Negeri 2 Daden, RT. 6 RW. II, \\ Majegan, Tulung, Klaten-Indonesia \\ endriana_wahyunisri@yahoo.com
}

\begin{abstract}
This research is to point out the colloquial styles and the meanings used in English songs. The writer took the data from the text of five cassettes consisting of twenty two English songs. The technique used was the purposive random sampling. The writer presented the data taken from the sample then used a qualitative analysis. The table shows a list of sentences from the sample songs (20 samples from 70 samples) having non Standard English. The findings of this study showed that the characteristics of colloquial style are used in English songs are structural aspect, denotative meanings and connotative meanings.
\end{abstract}

Keywords: Colloquial styles, English songs, structural aspect, denotative meanings and connotative meanings.

\begin{abstract}
Abstrak
Penelitian ini mengkaji bahasa pergaulan dan maknanya, yang digunakan dalam lagu-lagu bahasa Inggris. Penulis mengambil data dari lima lirik lagu dalam kaset yang terdiri dua puluh dua lagu bahasa Inggris. Teknik yang digunakan adalah sampel acak. Penulis menyajikan data yang diambil dari sampel, kemudian menggunakan analisis kualitatif. Tabel menunjukkan daftar kalimat dari sampel lagu (20 sampel dari 70 sampel) yang memiliki gaya Bahasa Inggris tidak baku. Temuan penelitian ini menunjukkan bahwa karakteristik gaya bahasa pergaulan yang digunakan dalam lagu-lagu bahasa Inggris adalah dalam aspek struktural, makna denotatif dan makna konotatif.
\end{abstract}

Kata Kunci: Gaya Bahasa Pergaulan, Lagu-Lagu Bahasa Inggris, Aspek Struktural, Makna Denotatif, Makna Konotatif 


\section{Introduction}

Word is one of the elements of language. Words can be formed into sentences and they give message which may have direct or indirect meanings. People create sentences with their own styles both in spoken and written forms. The use of language should be suited to the situation and purposes. In spoken language, expressive feelings and ideas sometimes are used with the gesture such as flashing eyes, moving the part of the body and other. While in the written forms, language is expressed with the choice of words in language style.

Based on its use, English can be divided into two (McCrimmon, 1967:170); Standard English and Nonstandard English. Standard English is known but prestige dialect which has social functions. It is, however, neither more logical and more complex, nor more regular than any other dialect. Any judgment, therefore, as to the superiority or inferiority of a particular dialect is social judgment, nor linguistics or scientific ones. Standard English is used most college educated people who fill position of social financial and professional influence in community. According to McCrimmon (1967: 174), Standard English has two variant, namely: formal English and informal English. Formal English is usually used in formal situations such as research, business letters, application letters, papers, thesis, seminar and so on. On the other hand, informal English is sometimes called colloquial English, because it is often used in daily communication in relaxed situations. Additionally, Widarso (1989: 51) says that nonstandard English is one of the variants English has which is not in line with the role of standard English.

Nonstandard English is considered as a non prestige variety. However, nonstandard English is not wrong. It is dialect spoken by a large section on non-middle class. The most noticeable characteristics of 
nonstandard English is the deletion of "g" consonant at the end of a word. Below are some examples of nonstandard words (Widarso, 1989: 52):

\section{Nonstandard English Standard English}

-Jessie ain't been here since last

-Jessie hasn't been here since last

month

month

-We ain't goin' nowhere -We aren't going anywhere

Sometimes nonstandard American English is used in English songs, which is intended means to make the songs more attractive and lovely. As a matter of fact, composing a song requires certain anilities and capabilities. The composer needs times to think, to choose the word, to read what she or the listener. Many songs use nonstandard English because nonstandard English is often more vivid and expressive compared to the standard variant. Besides, nonstandard English communicates more quickly and easily than standard English. Nonstandard English usually avoids sentimentality and formality. Thus, in this study the researcher formulated the problems as follows; (1) what colloquial styles are used in English songs? (2) what meanings are conveyed in colloquial style used in English songs?

\section{Colloquial Style}

The word colloquial is derived from Latin colloquialism (conversation). According to McCrimmon (1967: 173), the term is defined as a characteristic of an ordinary or familiar conversation rather than formal speech or writing. While Websters (1981: 162) states that colloquial is a word used in or characteristic of conversation, especially familiar and informal conversations. In this sense, colloquial style is used in daily speech or everyday conversation and it is more often used in speaking, rather than writing. Colloquial also refers to slang, which some linguists as low and vulgar. 


\section{Educated/Standard English}

Educated/standard English is often referred to as "the standard language". It is clear however, that standard English is not "a language" in any meaningful sense of this term (Bex: 1984:118). While Guth (1977:357) states that "Standard English" is the language of institutions, schools, churches and government. The standard English is a class dialect. It may be defined as the speech of those who enjoy a favored economic and social status in a society. In this sense, the standard English is used to denote the correct English used by educated speakers of English. It means that the term "standard English" is used to show the English is the way educated people speak and write. It is, therefore, the kind of English written and spoken by business executives, lawyers, doctors, ministers, teachers, writers, editors and other professional people. All these groups comprise only a small proportion of those who use the language.

\section{Formal English}

English has varieties, and formal English is one of them. Formal English is usually used in formal situations such as research, business letters, application letters, papers, thesis and seminar. Formal English is also used in oral report to the class, in a discussion of serious issues, or in a paper that treats a serious subject. According to Guth (1977:376), Formal English is the language of serious discussion.

\section{Informal English}

Informal English is used in daily conversations. Informal usages are found primarily in casual conversations. It is also used in writing designed to sound chatty or familiar. There are people who use informal English in nearly all of their conversations. Informal English is used by members of a family in 
their conversation and in writing letters to a close friend, by truck driver with cafeteria servants, etc.

\section{Uneducated/Nonstandard English}

Uneducated/Nonstandard English is a variety which does not agree with the rules of Standard English. McCrimmon (1967:170) states that nonstandard English is the language of those occupations which do not require "higher education".

Nonstandard English is often found is songs, poems and conversations. It is commonly used by Black Community in America Nonstandard English is spoken by many people in informal situations. Nonstandard English is the language of the factory, the mine, the lumber camp, the railroad and in general of those occupations which do not require "higher education". It is essentially spoken rather than written language, but it is often used in writing by novelists, dramatists, and short story writers when they are presenting characters who would be expected to use nonstandard English.

\section{Clipping}

There are many ways of forming new words in English, one of which is clipping. Clipping is a term referring to the formation of a new word, with the same meaning as the original lexical term, by cutting off a portion and reducing it to a monosyllabic or disyllabic form (Katamba, 1994: 182).

Clipping occurs when the longer word has very common use and a shorter form results because it is simpler and is easily understood. While gatherer (1986:11) says that clipped word can be formed by omitting part of a word. The omission is normally at the end or at the beginning of a word. 


\section{Slang}

Slang words, although currently popular, suggest a casual, forced, racy, vulgar, offbeat meaning. They may be used in informal oral communication, but they seldom have a place in more structured written communication. Slang words come and go so quickly. Another expert, Alwasilah (1985:47) says that slang is the introduction of new words. While Webster (1981:787) states that slang is the language peculiar to a particular group.

\section{Dictions}

According to Howard (1987:143), diction is the choice of words for the expression of ideas. While Hornby (1974:239) says that diction is choice and use of words, style or manner of speaking and writing.

\section{Research methodology}

The sample of this thesis was twenty English songs which have colloquial words or expressions. In this case, the writer took the data from the text of five cassettes consisting of twenty two English songs. In this research, the songs were categorized as follows:

\section{Pop Songs}

According to Hornby (1974: 648), the word "pop" is the depiction of scenes of everyday life, comic strips, commercial technique or those records sold in large number and those which are popular on radio, TV and in discotheques. While Websters (1981: 1765 ) says that "pop" is characterized by a popular tune or a mixture of popular and classical music intended to appeal to the people in general. 
The songs which were included in pop songs were those songs sung by Westlife and Britney Spears. Some of the songs are listed below: Season in the Sun, Fool Again, If I Let You Go, Stronger and Don't Let Me Be the Last to Know.

\section{Rock Songs}

Hornby (1974: 455) states that rock songs are highly rhythmic, popular music for dancing, played on electric guitars, etc. the songs which were included in rock songs, were those song sung by Gun'N Roses, New Kid on the Block and Ugly Kid Joe. Some of the rock songs for this study were: Don't Cry, Please Don't Go Girl, Same Side and Yesterdays.

In this thesis, the technique used was the purposive random sampling. A purposive sampling is a technique of taking sample by using a certain consideration determined by the writer (Ali: 1984: 54). This technique was used, based on the consideration that those songs were recently most popular.

The techniques of taking the data were as follows:

First, the writer selected the songs from five cassettes. The five cassettes consisted of five groups. They were: Westlife, Britney Spears, Gun 'N Roses, Ugly Kid Joe, New Kid on the Block. Second, the writer selected twenty two English songs from the five cassettes. Then, the writer compiled the lyrics of the songs that have been selected. Third, the writer read all the lyrics of the songs. Then, the fourth the writer selected words or expressions belonging to colloquial style and underlined them then put a number of each sentence in the songs which had colloquial words or expressions.

The steps for analyzing the data were: First, identifying the sentences which had colloquial words. Second, making a list of colloquial and standard 
words or expressions. Third, writing and classifying the sentences in the form of table. Then, fourth analyzing the sentences which had colloquial words or expressions in terms of their structural, diction and semantic aspects.

\section{Discussion}

In this research, the writer presented the data taken from the sample. The data were very important for the writer to show the object being research. In this research, the writer used a qualitative analysis. Qualitative refers to the meaning, the definition or analogy or model or metaphor characterizing something and it deals with the meaning of things, and one view of meaning is associative (Maanen, 1982: 31).

The table below shows a list of sentences (20 samples from 70 samples) having non-standard English. The sentences were taken from the sample songs.

\begin{tabular}{|c|c|c|c|}
\hline No. & Nonstandard English & No. & Standard English \\
\hline 01 & $\begin{array}{l}\text { Goodbye papa please pray for } \\
\text { me }\end{array}$ & 01 & $\begin{array}{l}\text { Goodbye father please pray for } \\
\text { me }\end{array}$ \\
\hline 02 & Baby, I know the story & 02 & Girl, I know the story \\
\hline 03 & $\begin{array}{l}\text { That you've been hiding } \\
\text { who's gonna take my place }\end{array}$ & 03 & $\begin{array}{l}\text { That you've been hiding } \\
\text { who's going to take my place }\end{array}$ \\
\hline 04 & I don't wanna you see us apart & 04 & $\begin{array}{l}\text { I don't want to you see us } \\
\text { apart }\end{array}$ \\
\hline 05 & $\begin{array}{l}\text { Listen to me hear what I say } \\
\text { 'cause when our love always }\end{array}$ & 05 & $\begin{array}{l}\text { Listen to me hear what I say } \\
\text { because when our love always }\end{array}$ \\
\hline 06 & I show you see what you doin' & 06 & I show you see what you \\
\hline
\end{tabular}




\begin{tabular}{|c|c|c|c|}
\hline & to me & & doing to me \\
\hline 07 & $\begin{array}{l}\text { Imagine two us together but I } \\
\text { been livin' in reality }\end{array}$ & 07 & $\begin{array}{l}\text { Imagine two us together but I } \\
\text { been living in reality }\end{array}$ \\
\hline 08 & $\begin{array}{l}\text { 'Cos I've got no fear of losin' } \\
\text { you }\end{array}$ & 08 & $\begin{array}{l}\text { Because I've got no fear of } \\
\text { losing you }\end{array}$ \\
\hline 09 & $\begin{array}{l}\text { Rules are made for breakin' } \\
\text { nothin' ventured nothin' } \\
\text { gained }\end{array}$ & 09 & $\begin{array}{l}\text { Rules are made for breaking } \\
\text { nothing ventured nothing } \\
\text { gained }\end{array}$ \\
\hline 10 & $\begin{array}{l}\text { Now I'm gonna confess that I } \\
\text { love you }\end{array}$ & 10 & $\begin{array}{l}\text { Now I'm going to confess that } \\
\text { I love you }\end{array}$ \\
\hline 11 & $\begin{array}{l}\text { I been keepin' it inside } \\
\text { feeling' I could die }\end{array}$ & 11 & $\begin{array}{l}\text { I been keeping it inside } \\
\text { feeling' I could die }\end{array}$ \\
\hline 12 & itside lookin' in & 12 & Here on the outside looking in \\
\hline 13 & $\begin{array}{l}\text { Don't wanna' stay dreamin' } \\
\text { 'bout what could have been }\end{array}$ & 13 & $\begin{array}{l}\text { Don't want to stay dreaming } \\
\text { about what could have been }\end{array}$ \\
\hline 14 & Baby, open your heart & 14 & Girl, open your heart \\
\hline 15 & I wanna make you mine & 15 & I want to make you mine \\
\hline 16 & $\begin{array}{l}\mathrm{N}^{\prime} \text { just can't get you off my } \\
\text { mind }\end{array}$ & 16 & $\begin{array}{l}\text { And just can't get you off my } \\
\text { mind }\end{array}$ \\
\hline 17 & $\begin{array}{l}\text { I've gotta go collect double } \\
\text { talkin' jive }\end{array}$ & 17 & $\begin{array}{l}\text { I've got to go collect double } \\
\text { talking jive }\end{array}$ \\
\hline 18 & $\begin{array}{l}\text { Back in town an' all new } \\
\text { friends }\end{array}$ & 18 & $\begin{array}{l}\text { Back in town and all new } \\
\text { friends }\end{array}$ \\
\hline 19 & They sayin' how ya been? & 19 & They saying' how you been? \\
\hline 20 & Fucked up and out place & 20 & Please go away \\
\hline
\end{tabular}


After reading, identifying the colloquial style and providing the standard expressions, the writer is going to present the characteristic of colloquial style on terms of structure, diction and meaning.

\section{A. Structural Aspects}

In term of structure, the characteristics of the colloquial style as used by the English songs are as follows:

1. Absence of be

$\underline{B e}$ as a full verb, has two forms i.e. past form (were, was) and present form (am, is, are), but in the songs these copulas were often absent in the sentences:

They sayin' how ya been? (No. 19)

(They saying' how you been?)

2. Deletion of ' $\mathrm{g}$ ' in the verb+ing form

In Standard English, the present continuous tense has a formula: $\mathrm{S}+$ to be + V-ing, but in nonstandard English the consonant ("g") is deleted in sentences as the following:

a. Don't let see your doin' to me (no. 06)

(' $\mathrm{g}$ ' in doin' is deleted)

b. Imagine two us together but I been livin' in reality (no. 07)

(' $\mathrm{g}$ ' in livin' is deleted)

c. Cos I've got no fear of losin' you (no. 08)

(' $\mathrm{g}$ ' in losin' is deleted)

d. Rules are made for breakin' nothin' ventured nothing; gained (no. 09)

(' $\mathrm{g}$ ' in breakin' and nothin' is deleted)

e. I been keepin' it inside feelin' I could die (no. 11)

(' $\mathrm{g}$ ' in keepin' and feelin' is deleted) 
f. Here on the outside lookin' in (no. 12)

(' $\mathrm{g}$ ' in lookin' is deleted)

g. Don't wanna stay dreamin' 'bout (no. 13)

(' $\mathrm{g}$ ' in dreamin' is deleted)

h. I gotta go collect double talkin' jive (no. 17)

(' $\mathrm{g}$ ' in dreamin' is deleted)

i. They sayin' how ya been (no. 19)

(' $\mathrm{g}$ ' in sayin' is deleted)

\section{B. Diction Aspect}

Any level of diction falls into one of the following three categories: standard, informal, colloquial (Howard: 1987: 55). In this study, there were two forms of diction used: informal and colloquial forms.

1. Informal Form

In standard English every word is written in full, but in the songs there were some forms which were simplified (clipped forms)

1) Cause when our love always fades away (no. 05) ('cause was simplified from because)

2) 'Cos I've got no fear of losin' you (no. 08) ('Cos was simplified from because)

3) Don't wanna stay dreamin 'bout (no. 13) ('bout was simplified from about)

4) N' just can't get you off my mind (no. 16) (N' was simplified from and)

5) Back in town an' all new friends (no. 18) (an' was simplified from and) 


\section{Colloquial Form}

a. Slang expressions used in the songs are presented below:

1) Good bye papa please pray for me (no. 01)

(the word papa was used to replace father)

2) Baby, I know the story (no. 02)

(the word baby was used to replace girl)

3) Who's gonna take me place (no. 03)

(the word gonna was used to replace going to)

4) I don't wanna you see us apart (no. 04)

(the word wanna was used to replace want to)

5) Now I'm gonna confess that I love you (no. 10)

(the word gonna was used to replace going to)

6) Don't wanna stay dreamin' 'bout what could have been (no. 13)

(the word wanna was used to replace want to)

7) Baby, open your heart (no. 14)

(the word baby was used to replace girl)

8) I wanna make you mine (no. 15)

(the word wanna was used replace want to

9) I gotta go collect double talkin' give (no. 17)

(the word gotta was used to replace got to)

10) Fucked up and out place (no. 20)

(the word fucked up and out place was used to replace go away)

b. In the songs, there were some form which had colloquial style.

1) Good bye papa please pray for me (no. 01)

(the word papa was used to replace father)

2) Baby, open your heart (no. 14) 
(the word baby was used to replace girl)

3) Fucked up and out place (no. 20)

(the word fucked up and out place was used to replace go away)

c. In the songs, the pronoun "you" was often pronounced (ja) and spelled (ya):

1) They sayin' how ya been (no. 19)

(You was pronounced ja)

\section{Semantic Aspect}

Semantic is the systematic study of meaning. Semantics is the study of how language organizes and expresses meaning (Kreidler, 1998: 3). According to Owens (1996:22), semantics is a system of rules governing the meaning on content of words and word combination. In this study, the words were analyzed in terms of their denotative and connotative meanings.

\section{Denotative Meaning}

The denotative meaning of a word refers to what the word actually point to (Hodges, 1984:226). While Howard (1987:48) says that denotative meaning is the dictionary meaning of a word. In English songs, the writer found some examples of denotative meaning.

a. Who's gonna take my place (no. 03)

(who is going to take my place)

b. I gotta collect double talkin' jive (no. 17)

(I've got to go collect double talkin' jive) 


\section{Connotative Meaning}

According to Howard (1987:48), connotative meaning is the emotional meaning of word. While Hodges (1984:226) says that connotative meaning is what the word suggest or simplifies.

In terms of connotative meaning, the writer found some sentences used in the English Songs, one of them is:

Fucked up and out place (no. 20)

(please go away)

\section{Conclusion}

Based on the previous discussion, the following conclusion was drawn: (1) the characteristics of colloquial style are used in English songs; structural aspect (be as full verb in the songs was often absent in the sentences, and in nonstandard English the consonant (g) is replaced with (n') in the last word) and diction aspect (clipped forms, slang words, and colloquial styles are used, also 'Ya' sometimes replaces 'you'). (2) Denotative meanings make the listener and the readers understand more about the songs. Besides, there were also connotative meanings conveyed in the songs; papa (the word "papa" are used in the songs to have the denotative meanings by "father". This words is used in the songs, because in the closeness in family context and to describe that "papa" is a man of character and respectability) and baby (the word "baby" are used in the songs to have the denotative meaning by "girl". This word is used in the songs, because the girls to baby a child and to describes that the man have close relationship with someone's or the man, to fall in love with his girl, so the man gave her full of love and care attention). 


\section{References}

Ali, M., 1984. Penelitian Kependidikan Prosedur dan Strategi. Bandung: Angkasa Bandung

Alwasilah, A.C. 1985. Sosiologi Bahasa. Bandung: Angkasa Bandung.

Bex, T. and Watts, RJ. 1984. Standard English the Widening Debate. New York: Routledge.

Gatherer, WA. 1986. The Students Handbook of Modern English. Jakarta: PT Gramedia

Guth, Hans P. 1977. American English Today. New York: McGraw-Hill Book Company.

Hodges, John C. 1984. Harbace College Handbook. New York, Harcout Brace and World, Inc.

Hornby, AS. 1974. Oxford Advanced Learner's dictionary of Current English. Great Britain: Oxford University Press

Howard, C. Jerriel. 1987. The Essential English Handbook and Rethoric, Indianapolis: Bobbs Merril Education Publishing.

Katamba, F. 1994. English Words. New York:Routledge

Kreidler, C. 1998. Introducing English Semantics. London: Rotledge.

Maanen, JV and Dabbs, JM. 1982. Varieties of Qualitative Research. London Sage Publications.

McCrimmon, JM. 1967. Writing with A Purpose from Source to Statement. New York: Houghton Mifflin Company.

Owens. Jr. R. E. 1996. Language Development: An Introduction. New York: State University of New York, $4^{\text {th }}$ Edition

Websters, 1981. Third New International Dictionary of the Language Unabridge, Chicago:Encyclopedia Britanica, Inc.

Widarso, Wisnubroto. 1989. Bahasa Inggris, Dialek, Ragam, Jargon, Slang, Blends, Clipped Words. Yogyakarta: Kanisius. 